\title{
Genetic Diversity and Joint-Pedigree Analysis of Two Importing Holstein Populations
}

\author{
H. Hammami, ${ }^{*} \dagger$ C. Croquet, ${ }^{*} \ddagger$ J. Stoll, $\S$ B. Rekik, $\|$ and N. Gengler $\ddagger^{1}$ \\ *Animal Science Unit, Gembloux Agricultural University, B-5030 Gembloux, Belgium \\ †Livestock and Pasture Office, 1002 Tunis Belvedere, Tunisia \\ $\ddagger$ National Fund for Scientific Research, B-1000 Brussels, Belgium \\ $\S C O N V I S$ Herdbuch, Service Elevage et Génétique, L-9004 Ettelbruck, Luxembourg \\ |Ecole Supérieure d'Agriculture de Mateur, 7030 Mateur, Tunisia
}

\begin{abstract}
Genetic diversity and relatedness between 2 geographically distant Holstein populations (in Luxembourg and Tunisia) were studied by pedigree analysis. These 2 populations have similar sizes and structures and are essentially importing populations. Edited pedigrees included 140,392 and 151,381 animals for Tunisia and Luxembourg, respectively. To partially account for pedigree completeness levels, a modified algorithm was used to compute inbreeding. The effective numbers of ancestors were derived from probabilities of gene origin for the 2 populations of cows born between 1990 and 2000 . The 10 ancestors with the highest contributions to genetic diversity in the cow populations accounted for more than $32 \%$ of the genes. Eight of these 10 ancestors were the same in both populations. The rates of inbreeding were different in the 2 populations but were generally comparable to those found in the literature for the Holstein breed. Average inbreeding coefficients per year, estimated from the data, ranged from 0.91 and 0.50 in 1990 to 3.10 and 2.12 in 2000 for the Tunisian and Luxembourg populations, respectively. Genetic links have also strengthened with time. Average additive relationships between the 2 populations were as high as $2.2 \%$ in 2000 . Results suggest that it would be possible to investigate genotype by environment interactions for milk traits using the Tunisian and Luxembourg dairy populations.
\end{abstract}

Key words: pedigree, probability of gene origin, inbreeding, genetic diversity

\section{INTRODUCTION}

The Holstein breed is known worldwide as one of the highest yielding dairy breeds. Breeding strategies

Received October 17, 2006.

Accepted March 28, 2007.

${ }^{1}$ Corresponding author: gengler.n@fsagx.ac.be

Note: Affiliation changed for N. Gengler in this corrected paper. to improve milk production, based on the import of purebred Holstein heifers and semen, have been implemented by many developed and developing countries over the last $40 \mathrm{yr}$. Tunisia imported purebred pregnant Friesian heifers from the Netherlands in 1970 (Djemali and Berger, 1992). Holsteins were then imported from Canada, the United States, and some European countries. Luxembourg has a similarly sized dairy cattle population to that of Tunisia. The Luxembourg population originally included one-third Red and White dairy cows. Breeders in Luxembourg, like their Tunisian counterparts, imported heifers mainly from Germany. The current breeding scheme in Luxembourg is also similar to that in Tunisia. In the absence of a national progeny-testing program, this scheme is based on imported semen of proven bulls, with a very limited use of young sires. On the other hand, breeding goals vary between the 2 countries. In Tunisia, the focus is on increased yield by means of an intraherd index used to select cows, whereas breeders in Luxembourg rely on the RZG selection index obtained following a joint genetic evaluation with Germany. The RGZ composite index includes durability, health, and reproduction traits in addition to milk yield (Miglior et al., 2005).

The intensive use of AI from a few proven sires throughout the world may result in increased levels of inbreeding. The reduced genetic diversity may hamper the success of future breeding strategies in dairy cattle. The genetic variability in a population is influenced by the number of founders, selection intensity, inbreeding, and genetic drift. Measures of genetic diversity such as effective number of founders and ancestors have recently been used to evaluate genetic variability in several species: cattle (Boichard et al., 1996; Sölkner et al., 1998; Roughsedge et al., 1999; Honda et al., 2004; Hagger, 2005), horses (Valera et al., 2005), donkeys (Gutiérrez et al., 2005), and dogs (Leroy et al., 2006). Most of these studies were carried out using data on specific country populations; others extended 
their study to different breeds (Sørensen et al., 2005). Investigations on dairy cattle have been based on large populations with structures involving no or little imported cattle or semen.

Genetic diversity analyses in developing countries are scarce, as are studies on genetic links among geographically distant Holstein populations. Very few studies have combined both, even if they must be addressed to investigate genotype by environment interactions and to monitor breeding programs. The objectives of this study were therefore twofold. The first objective was to measure genetic diversity for the Luxembourg and Tunisian Holstein populations given their specific situation as importing countries. The second objective was to assess genetic links between these 2 geographically distant Holstein populations.

\section{MATERIALS AND METHODS}

\section{Data}

Tunisian data were provided by the Center for Genetic Improvement of the Livestock and Pasture Office (OEP). Original data included 102,890 pedigree records. Records were of milk-recorded cows born between 1990 and 2000 (sired by 3,482 AI bulls) and their registered ancestors. Individual identity was registered following the appropriate numbering system given by the herd book of origin and contained parents and grandparents. For all animals in the original pedigree file, reference identification (ID) according to the international ID structure was obtained. Sire identifications were cross-checked with the Interbull crossreference files for imported bulls. Similarly, herd-book files were cross-checked for imported heifer identifications. Pedigree depth was improved by using North American pedigree files provided by the Canadian Dairy Network (Guelph, Ontario, Canada) and the Animal Improvement Programs Laboratory (Beltsville, MD) and similar European herd-book files. The final Tunisian pedigree data included 140,392 records of animals born between 1917 and 2000. Each record included the international ID number, country of origin, birth year, sire, and dam of the animal.

Original Luxembourg pedigree data were obtained from the Luxembourg Herd-Book Federation (now CONVIS Herdbuch, Service Elevage et Génétique, Ettelbruck, Luxembourg) and were provided by United Datasystems for Animal Production [Vereinigte Informationssyteme Tierhaltung (VIT), Verden, Germany]. Data included 125,134 pedigree records. Animals were identified according to an international ID. Records were of all milk-recorded cows born between 1990 and 2000 , along with those of their ancestors. Sire identifications were cross-checked with the Interbull cross- reference files for imported bulls. As with the Tunisian data, the Luxembourg pedigree file was also improved by adding depth through the use of foreign files. The final Luxembourg data included 151,381 animals born between 1917 and 2000. Tunisian and Luxembourg files were then merged. There were 16,856 pedigree records in common, and the final pedigree used in the analysis included 259,659 animals. Figure 1 shows the evolution of records from 1941 to 2000 for both populations. The rate of registration was low before 1980. Percentages of animals registered after 1980 were 81 and $62 \%$ for Luxembourg and Tunisia, respectively.

The definition of a reference population was necessary to allow comparisons. It had to be similarly defined for Luxembourg and Tunisia. This population was made up of cows with at least one test-day record and born between 1990 and 2000. Reference populations included 75,467 and 47,321 cows for Luxembourg and Tunisia, respectively. The reference period was defined to represent the last 2 generations of cows available for this study. No other edits were made. Cows in the reference populations were mainly daughters of AI bulls. The latter represented 82 and $85 \%$ of all sires registered in Tunisia and Luxembourg, respectively. These bulls were almost exclusively proven foreign sires for Tunisia (99\%), whereas Luxembourg has recently used a few young bulls (8\%) in addition to proven foreign ones.

\section{Pedigree Completeness}

The pedigree completeness level was evaluated for the 2 reference populations. The fractions of known ancestors per generation were computed and the average numbers of ancestors by year of birth were traced. Updating the pedigrees led to a considerable increase in the average number of known ancestors in both populations. Cows in Luxembourg had more unknown parents than those in Tunisia. A little was gained by cross-checking with foreign files in the case of Luxembourg.

The number of known generation equivalents was then computed for each animal. This number was derived as the sum of the $(1 / 2)^{\mathrm{n}}$ coefficients, where $\mathrm{n}$ is the number of generations separating animals from the known ancestor. Therefore, a parent accounts for 0.5 and a grandparent for 0.25 , and so on. Finally, average numbers of known generation equivalents were obtained by birth year for the 2 reference populations. The average number of generation equivalents quantifies how many generations have been traced. After pedigree improvements, the average number of known generation equivalents increased from 5.4 and 


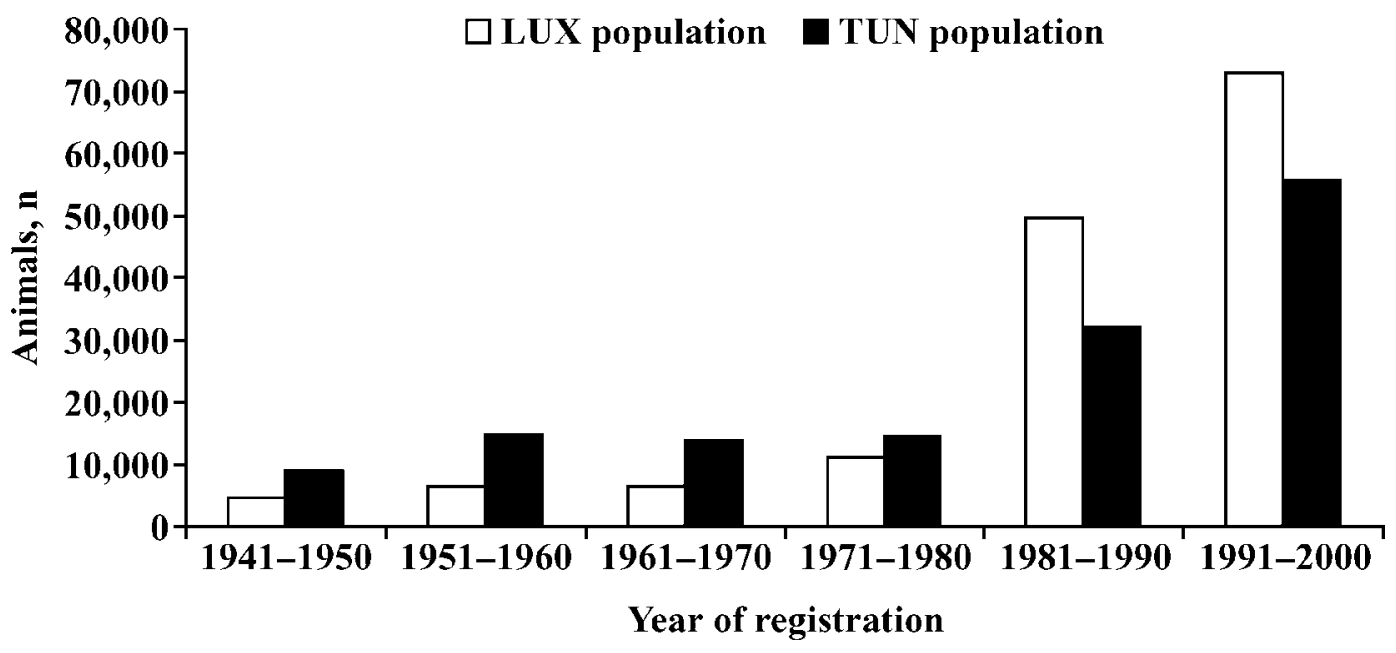

Figure 1. Number of registrations in Luxembourg (LUX) and Tunisian (TUN) herd books by periods of $10 \mathrm{yr}$.

$4.2 \mathrm{yr}$ in 1990 to 8.2 and $6.3 \mathrm{yr}$ in 2000 for the Tunisian and Luxembourg reference populations, respectively (Figure 2). Percentages of cows with unknown sires were 32 and $5 \%$ of the Luxembourg and Tunisian reference populations, respectively. Percentages of cows with unknown dams were 17 and $14 \%$, respectively.

\section{Methods}

Inbreeding. To account for trends in inbreeding even when ancestors were missing, a genetic group for each animal was defined by sex, country, and birth year. Dams without pedigree records were assigned to the year of birth of their oldest progeny minus 3 . Sires without pedigree records were assigned to the year of birth of their oldest progeny minus 5 . The inbreeding coefficients were then computed according to the methodology described in Croquet et al. (2006) and based on the algorithm of Meuwissen and Luo (1992). In the method by Croquet et al. (2006), the estimated inbreeding coefficient of an animal with unknown origins is equal to half the average relationship between
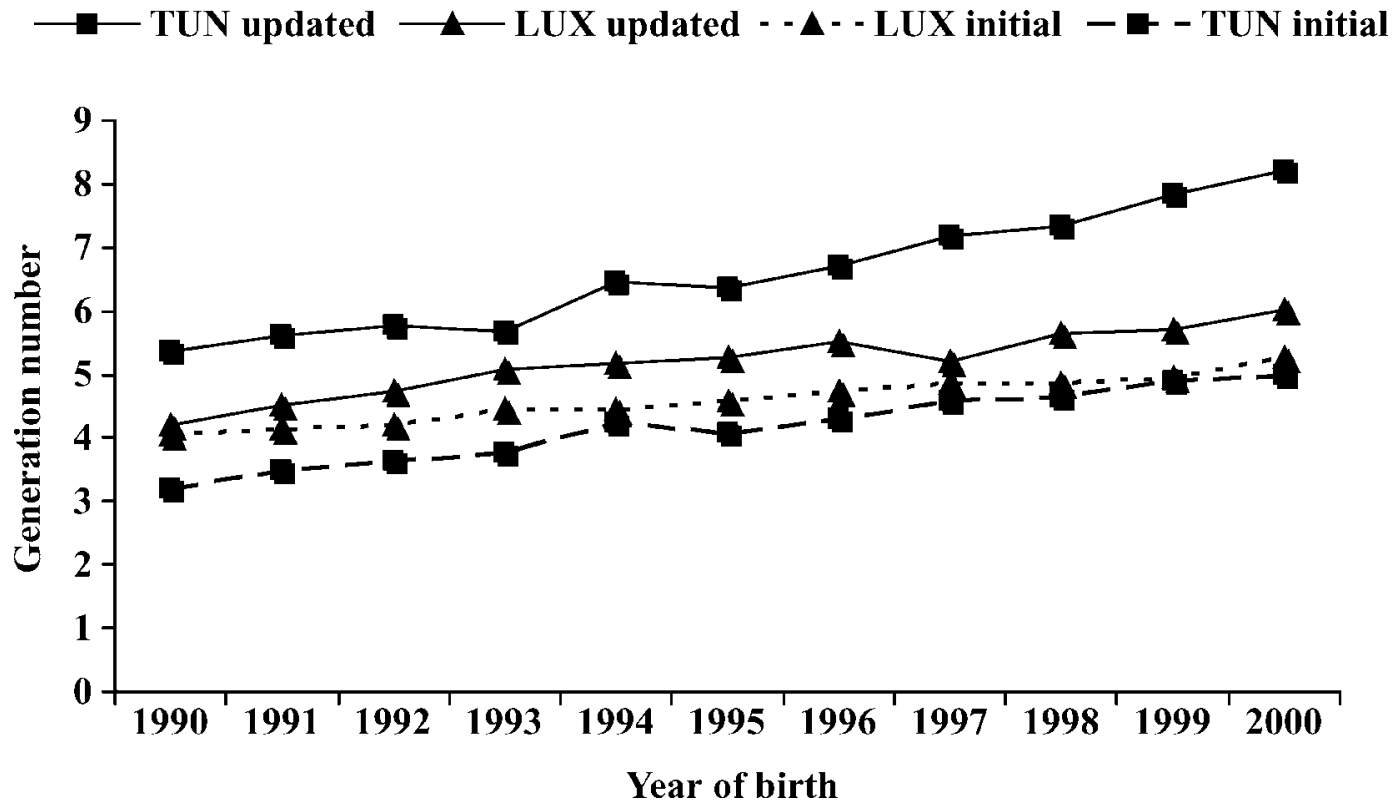

Figure 2. Average number of known generation equivalents by year of birth for the reference populations of cows born between 1990 and 2000 in Tunisia (TUN) and Luxembourg (LUX). Initial means: pedigree as delivered by CONVIS (CONVIS Herdbuch, Service Elevage et Génétique, Ettelbruck, Luxembourg; LUX) and the Center for Genetic Improvement of the Livestock and Pasture Office (OEP; TUN). Updated means: edited pedigree using cross-reference files and international databases. 
genetic groups of its phantom parents. Average and maximum coefficients of inbreeding were computed for the populations of both countries, assuming that animals of unknown origin had inbreeding coefficients similar to the average of comparable animals. Animals were considered comparable if they were born in the same year, had the same sex, and came from the same population.

Effective Number of Founders. Each individual with unknown parents was considered as a founder. Furthermore, if an animal had one known and one unknown parent, the unknown parent was regarded as a founder. The expected genetic contribution of each founder to the reference population was defined as the probability of a gene taken at random within the reference population to come from a given founder. The genes of an animal have a 0.5 probability of originating from its sire and a 0.5 probability of originating from its dam. Similarly, it has a 0.25 probability of originating from any of the animal's grandparents and so on. When this rule is applied to a population and the probabilities are accumulated by founders, each founder $\mathrm{k}$ is characterized by its expected contribution $q_{k}$ to the gene pool of the population.

The total number of founders (f) in these data is expected to be very high because of missing pedigree and therefore may not fully explain genetic variability in the reference population. First, these founders are assumed to be unrelated because their parents are unknown, which is likely not the case. Second, their contributions to the reference populations may vary. Intensively used founders will contribute more to the reference population than the others. To take account for this, the effective number of founders $\left(f_{e}\right)$ was estimated. This number was defined as the number of equally contributing founders that would be expected to produce the same genetic diversity in the populations under study (Lacy, 1989). This number is given by

$$
\mathrm{f}_{\mathrm{e}}=\frac{1}{\sum_{\mathrm{k}=1}^{\mathrm{f}} \mathrm{q}_{\mathrm{k}}^{2}}
$$

where frepresents the number of founders and $q_{k}$ is the genetic contribution of the $k$ th founder to the reference population. When founders contribute equally, the effective number of founders is equal to the total number of founders. Otherwise, the effective number of founders remains smaller than the total number of founders.

Effective Number of Ancestors. The effective number of ancestors was proposed by Boichard et al. (1997) as an alternative to the effective number of founders. It also takes into account bottlenecks in pedi- grees. Ancestors here can be founders or not. The effective number of ancestors $\left(f_{a}\right)$ represents the minimum number of equally contributing ancestors (founders or not) that are necessary to explain the complete genetic diversity in a population. The expected marginal contribution $\left(p_{j}\right)$ of each ancestor $(j)$ was computed as its expected genetic contribution independently of the contributions of other ancestors. The ancestor with the highest genetic contribution to the population is first chosen, and the other ancestors are selected iteratively. In round $\mathrm{n}$, the kth ancestor is chosen according to its marginal contribution $\left(p_{\mathrm{k}}\right)$. This latter is defined as the contribution of the kth ancestor not yet explained by the $(\mathrm{k}-1)$ ancestors already being chosen. Then, based on these marginal contributions, another ancestor is chosen, and so on. The effective number of ancestors is computed as

$$
f_{a}=\frac{1}{\sum_{k=1}^{f} p_{k}^{2}},
$$

where $p_{k}$ is the marginal genetic contribution of the $\mathrm{kth}$ ancestor not yet explained by the previous ( $\mathrm{k}-$ 1 ) ancestors, and $f$ is the number of ancestors. The marginal contribution was determined for 1,000 ancestors in this study. The number of ancestors with a positive marginal genetic contribution is less than or equal to the total number of founders. The effective number of ancestors is more accurate than the effective number of founders to measure genetic diversity. The classic and simple approach for estimating the effective number of founders overestimates the former when the pedigree is undergoing a bottleneck. Let us consider an example in which the reference population is simply a set of full sibs from 2 unrelated parents. When the grandparents are considered, the effective number of founders computed is 4 and is multiplied by 2 for each additional traced generation, whereas the effective number of ancestors is 2 (the 2 parents). This overestimation is particularly important when the germplasm of a limited number of breeding animals is widely spread, which is the case of the 2 populations in this study because of the intensive use of a few AI bulls. The effective number of ancestors takes into account the most recent bottlenecks. However, it should be used in parallel with the effective number of founders. The effective number of ancestors does not take into account the probabilities of gene losses by drift.

Relatedness Between Populations. The additive genetic relationship coefficients within and between Tunisian and Luxembourg female reference populations were calculated following the algorithm by Boi- 
Table 1. Numbers of founders and ancestors for the Tunisian and Luxembourg populations of cows born between 1990 and 2000

\begin{tabular}{|c|c|c|c|c|c|c|}
\hline \multirow[b]{2}{*}{ Country } & \multicolumn{6}{|c|}{ Birth year } \\
\hline & 1990 & 1992 & 1994 & 1996 & 1998 & 2000 \\
\hline & \multicolumn{6}{|c|}{ Total number of founders } \\
\hline Luxembourg & 9,089 & 9,111 & 9,231 & 9,261 & 9,522 & 9,328 \\
\hline \multirow[t]{2}{*}{ Tunisia } & 8,949 & 10,386 & 10,458 & 10,936 & 12,196 & 10,794 \\
\hline & \multicolumn{6}{|c|}{ Effective number of founders } \\
\hline Luxembourg & 373 & 387 & 332 & 313 & 305 & 295 \\
\hline \multirow[t]{2}{*}{ Tunisia } & 194 & 194 & 153 & 136 & 123 & 112 \\
\hline & \multicolumn{6}{|c|}{ Effective number of ancestors } \\
\hline Luxembourg & 97 & 75 & 55 & 50 & 47 & 44 \\
\hline \multirow[t]{2}{*}{ Tunisia } & 49 & 46 & 33 & 29 & 28 & 22 \\
\hline & \multicolumn{6}{|c|}{ Number of ancestors accounting for $50 \%$ of the gene pool } \\
\hline Luxembourg & 57 & 57 & 46 & 31 & 26 & 24 \\
\hline Tunisia & 34 & 26 & 19 & 15 & 13 & 9 \\
\hline
\end{tabular}

chard (2002). This algorithm builds up the relationship matrix, term by term, by generating a progeny for each combination from which the inbreeding coefficient was derived following the method of Meuwissen and Luo (1992). Pairwise genetic relationship coefficients between sires used in the 2 reference populations were also estimated. Furthermore, an average genetic relationship coefficient between proven bulls born in 1995 and originating from various Interbull country members and living females during 1999 in Luxembourg and in Tunisia was obtained. The birth year of 1995 was chosen to hypothetically suggest that bulls born in 1995 could be potential sires of cows born in 1999 in Tunisia and Luxembourg.

Finally, the genetic similarity (GS) between the Luxembourg and Tunisian cow populations was computed following Rekaya et al. (2003). Genetic similarity was defined as the ratio of the number of daughters of common bulls to that of all bulls:

$$
\mathrm{GS}(\mathrm{i}, \mathrm{j})=\sum_{\mathrm{r}=1}^{2} \sum_{\mathrm{k}=1}^{\mathrm{C}(\mathrm{i}, \mathrm{j})} \mathrm{ND}_{\mathrm{kr}} / \sum_{\mathrm{r}=1}^{2} \sum_{\mathrm{k}=1}^{\mathrm{T}(\mathrm{i}, \mathrm{j})} \mathrm{ND}_{\mathrm{kr}}
$$

where $\mathrm{C}(\mathrm{i}, \mathrm{j})$ is the number of bulls in common used in country $i$ and $j, T(i, j)$ is the total number of bulls used in both countries, and $\mathrm{ND}_{\mathrm{kr}}$ is the number of daughters of bull $\mathrm{k}$ in country $\mathrm{r}(\mathrm{r}=1,2)$.

\section{RESULTS}

The effective number of founders $\left(f_{e}\right)$ differed between the 2 reference populations (Table 1 ) for the 1990 to 2000 period. This number was higher for the
Luxembourg population than the Tunisian population. The effective number of ancestors was smaller than that of the founders. The former was also lower in the Tunisian than in the Luxembourg population. The effective numbers of founders were 112 and 295 for the Tunisian and Luxembourg Holstein populations in 2000 , respectively. These effective founders corresponded to 22 and 44 effective ancestors, respectively (Table 1). From 1990 until 2000, the effective numbers of ancestors decreased by almost $60 \%$ in both countries.

Total numbers of ancestors contributing $50 \%$ of the gene pool were low and tended to decrease from 1990 to 2000 in both countries. Cumulative marginal contributions of ancestors showed similar patterns in both populations (Figure 3). A small number of ancestors contributed heavily to the reference populations, whereas the rest of the genes came from a great number of ancestors with low marginal contributions. The most popular ancestors with the largest marginal contributions to the reference populations (33\% in Luxembourg and $42 \%$ in Tunisia) are given in Table 2 . It is interesting to note that the 10 most important ancestors of Luxembourg Holsteins explained approximately $40 \%$ of the genetic diversity in the Tunisian female population. The specific presence of Hanover Hill Triple Threat in Luxembourg can be explained by the fact that this sire was specifically used in Red Holstein populations and that the Luxembourg dairy cattle population had historically one-third Red and White cows.

Inbreeding trends for females raised in Luxembourg and in Tunisia between 1990 and 2000 are shown in Figure 4. Inbreeding levels prior to 1990 (not given) 


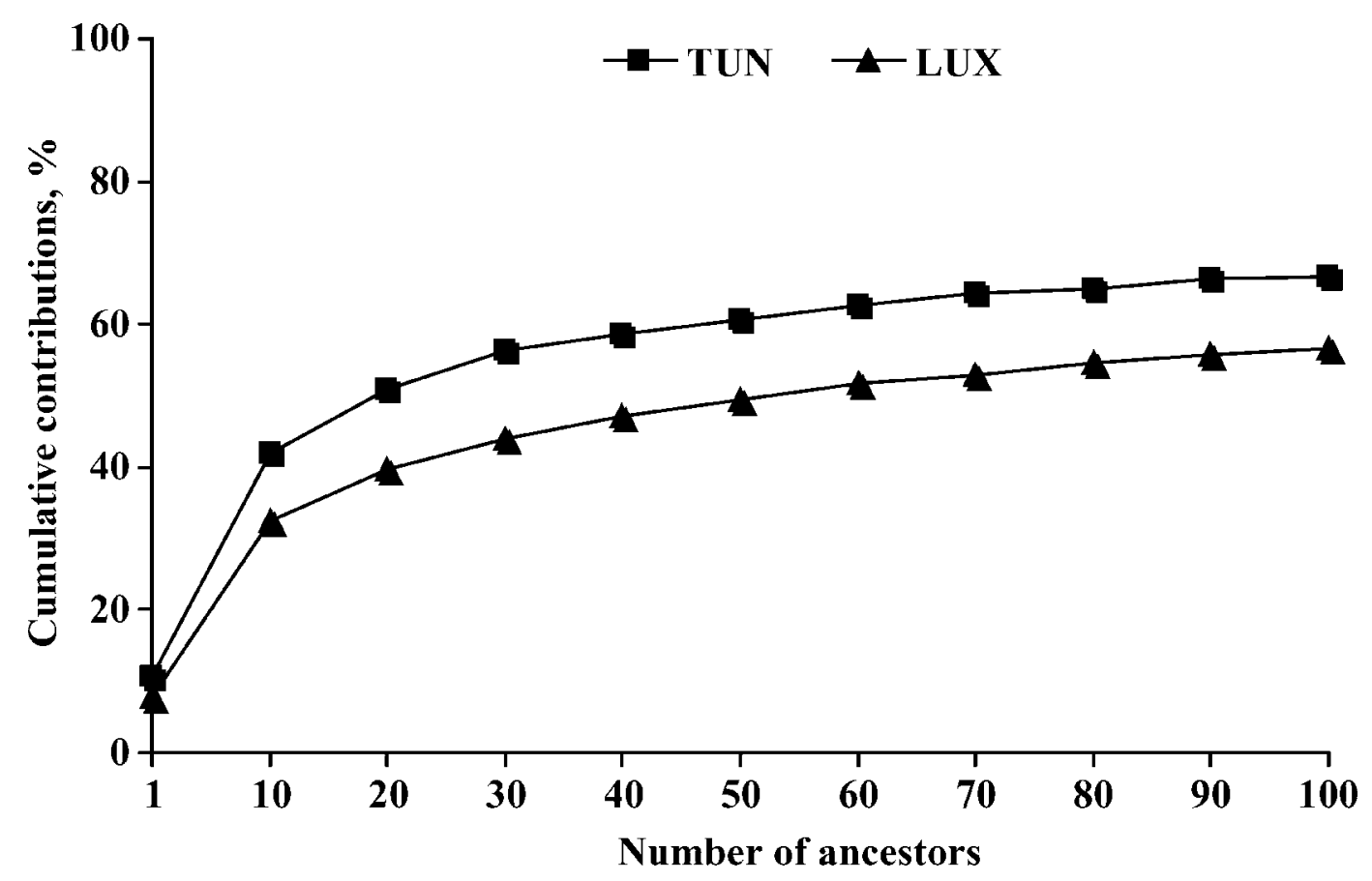

Figure 3. Cumulative marginal genetic contributions of ancestors to the Tunisian (TUN) and Luxembourg (LUX) Holstein populations.

were low in both countries and varied from 0.042 and $0.04 \%$ in 1983 to 0.97 and $0.3 \%$ in 1989 for the Tunisian and Luxembourg populations, respectively. The level of inbreeding observed for the Tunisian reference population $(3.10 \%)$ was higher than that observed for the Luxembourg population (2.12\%). Differences between average inbreeding coefficients of the Luxembourg and Tunisian populations doubled from 1990 to 2000.

Averages of pairwise genetic relationship coefficients are shown in Figure 5. Curves illustrating the rates of change in additive relationships within each population were steeper than those of inbreeding trends. Additive relationships in the Tunisian reference female population increased by approximately $0.25 \%$ each year. Relationship coefficients within the Tunisian reference population were higher than those found within the Luxembourg population. The buildup of additive relations was also slower within the Luxembourg female population.

Average pairwise relationships between the sires of cows born in Tunisia and Luxembourg between 1990 and 2000 (Table 3) were greater than those between their daughters (Figure 5). There is considerable variation in relationship levels among sires used in the 2

Table 2. Marginal genetic contributions (\%) to the Luxembourg and Tunisian cow populations by the most popular ancestors ranked on their contributions to the Luxembourg population

\begin{tabular}{lrrrrr}
\hline & \multicolumn{2}{c}{ Luxembourg } & & \multicolumn{2}{c}{ Tunisia } \\
\cline { 2 - 3 } \cline { 5 - 6 } Ancestor & Rank & Contribution, \% & & Rank & Contribution, \% \\
\hline Round Oak Rag Apple Elevation & 1 & 7.87 & & 2 & 10.35 \\
Pawnee Farm Arlinda Chief & 2 & 5.73 & & 1 & 10.70 \\
Osborndale Ivanhoe & 3 & 3.46 & & 3 & 4.95 \\
Hanover Hill Triple Threat & 4 & 3.21 & & $(>1,000)$ & $(<0.01)$ \\
Paclamar Astronaut & 5 & 3.04 & & 6 & 2.42 \\
Dam of SWD Valiant & 6 & 2.64 & & 5 & 3.18 \\
ABC Reflection Sovereign & 7 & 2.19 & & 9 & 1.55 \\
Carlin-M Ivanhaoe Bell & 8 & 1.74 & & 4 & 3.38 \\
Wisconsin Admiral Burke Lad & 9 & 1.4 & & $(33)$ & $(0.3)$ \\
No-Na-Me Fond Matt & 10 & 1.07 & & 7 & 2.15 \\
Paclamar Bootmaker & $26)$ & $0.42)$ & & 10 & 1.35 \\
Whittier-Farms Ned Boy & $(>1,000)$ & $(<0.01)$ & & 8 & 1.83 \\
Total contribution & & 32.35 & & & 41.86 \\
\hline
\end{tabular}




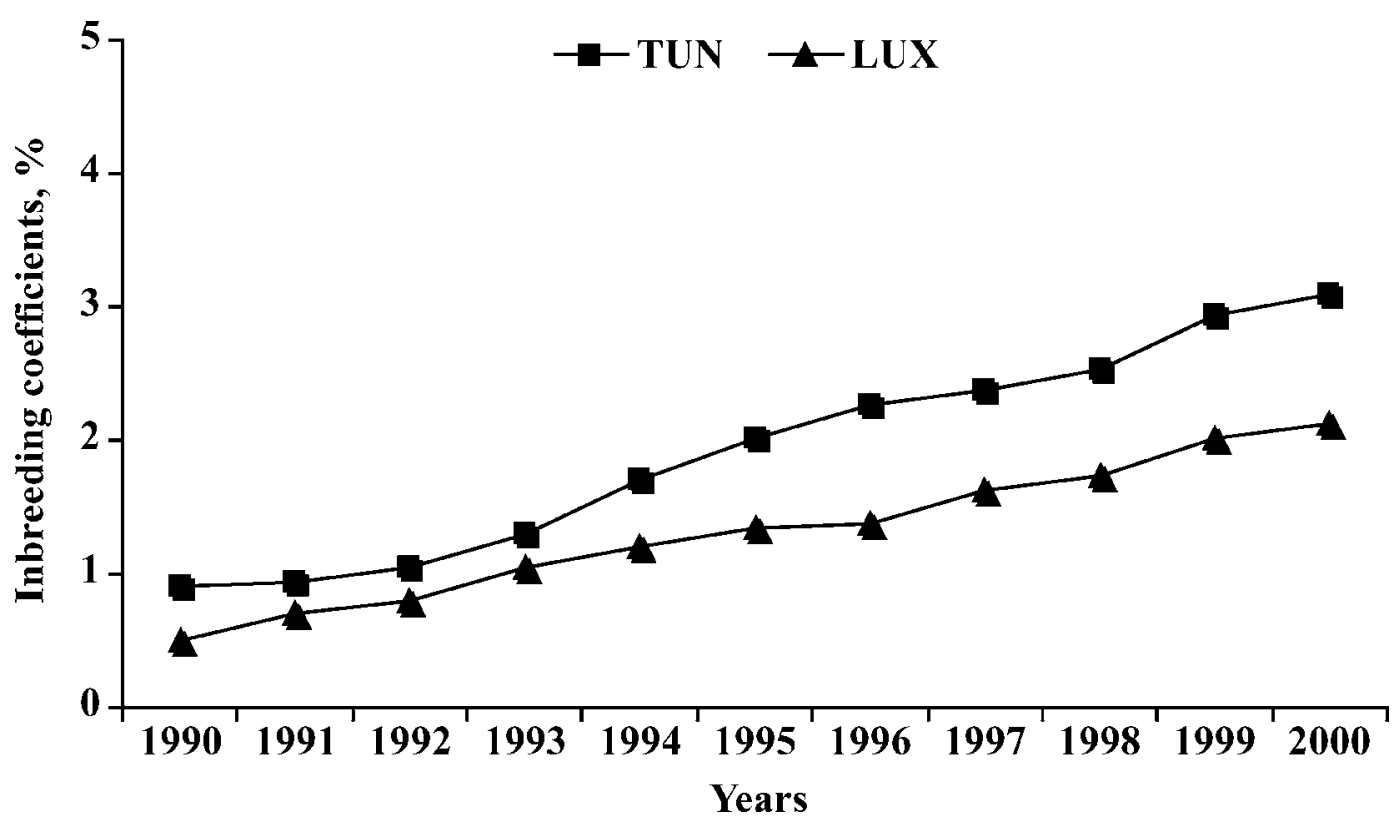

Figure 4. Inbreeding trends for Tunisian (TUN) and Luxembourg (LUX) Holstein female populations.
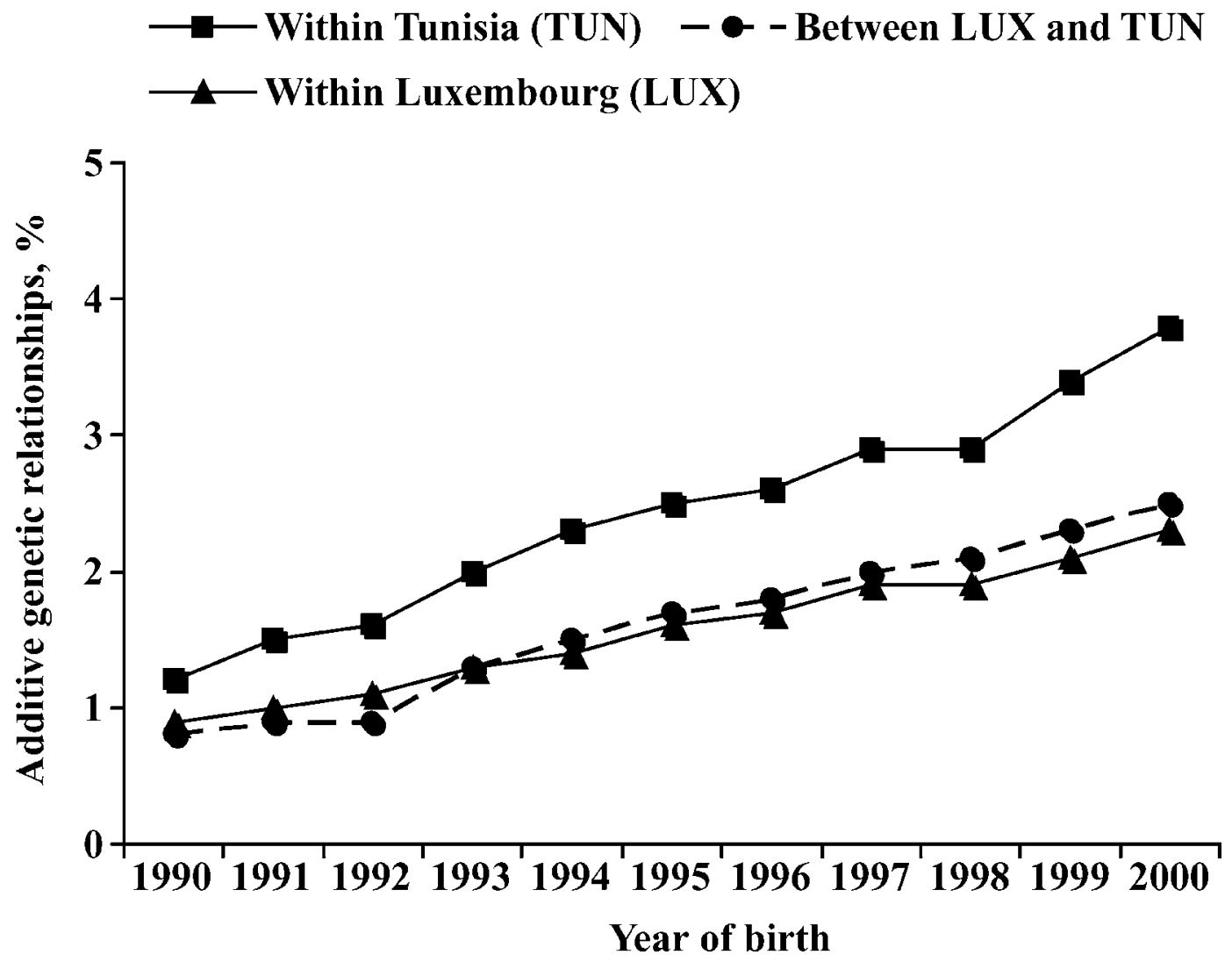

Figure 5. Average pairwise additive relationships within and between Luxembourg (LUX) and Tunisian (TUN) Holstein cows born between 1990 and 2000 . 
Table 3. Average pairwise relationship (AR) between sires of cows born from 1990 to 2000 in Luxembourg and Tunisia

\begin{tabular}{lcccc}
\hline $\begin{array}{l}\text { Birth year } \\
\text { of cows }\end{array}$ & $\begin{array}{c}\text { Average } \\
\text { relationship, } \%\end{array}$ & SD, \% & $\begin{array}{c}\text { Percentage } \\
\text { of sires } \\
\text { with AR } \leq 1 \%\end{array}$ & $\begin{array}{c}\text { Percentage } \\
\text { of sires } \\
\text { with AR } \geq 6 \%\end{array}$ \\
\hline 1990 & 2.4 & 2.8 & 39 & 10 \\
1991 & 2.9 & 3.2 & 34 & 14 \\
1992 & 3.0 & 3.3 & 33 & 15 \\
1993 & 3.1 & 3.2 & 30 & 14 \\
1994 & 3.2 & 3.1 & 23 & 16 \\
1995 & 3.7 & 3.2 & 18 & 16 \\
1996 & 3.9 & 3.2 & 15 & 20 \\
1997 & 4.3 & 3.4 & 11 & 20 \\
1998 & 4.3 & 3.3 & 8 & 22 \\
1999 & 4.5 & 3.4 & 6 & 24 \\
\hline
\end{tabular}

countries during the $11 \mathrm{yr}$ of the study $(\mathrm{SD}>3 \%)$. The proportion of sires with less than $1 \%$ relationship coefficients decreased from one year to another, whereas that of sires with more than $6 \%$ relationship coefficients did increase.

Tested bulls from the United States, Spain, Italy, and Canada born in 1995 had the highest percentage of genes in common with the Tunisian (average relationship coefficients $\geq 4 \%$ ) and Luxembourg (average relationship coefficients $\geq 2 \%$ ) cows living in 1999 (Figure 6). Bulls originating from the Republic of South Africa, France, Japan, the United Kingdom, Denmark, Sweden, Australia, and the Netherlands had the next highest average coefficients compared with the Luxembourg $(>1.5$ and $<2 \%)$ and Tunisian $(\geq 3$ and $<4 \%)$ female subpopulations of 1999. At the end of the spectrum of Figure 6, there are bulls originating from Israel, Switzerland, Poland, and Estonia, which were

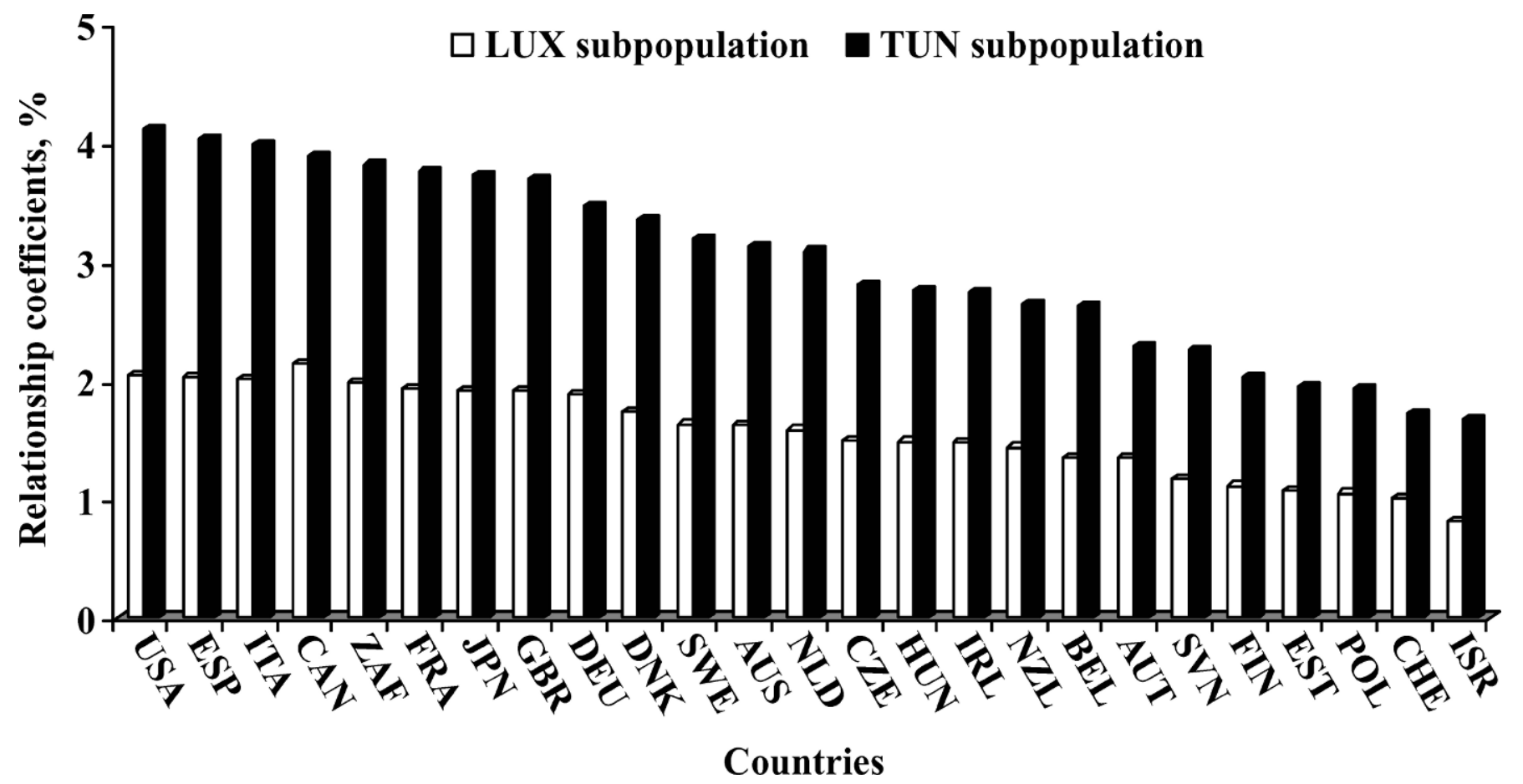

Figure 6. Average relationships between females living in Luxembourg (LUX) and Tunisia (TUN) in 1999, and tested bulls in Interbull country members born in 1995. USA = United States; ESP = Spain; ITA = Italy; CAN = Canada; ZAF = Republic of South Africa; FRA = France; JPN = Japan; GBR = Great Britain; DEU = Germany; DNK = Denmark; SWE = Sweden; AUS = Australia; NLD = the Netherlands; CZE = Czech Republic; HUN = Hungary; IRL = Ireland; NZL = New Zealand; BEL = Belgium; AUT = Austria; SVN = Slovenia; FIN = Finland; EST = Estonia; POL = Poland; CHE = Switzerland; ISR = Israel. 
Table 4. Genetic links between the Luxembourg and Tunisian Holstein populations

\begin{tabular}{|c|c|c|c|c|}
\hline \multicolumn{3}{|c|}{$\begin{array}{l}\text { Sires with daughters having test day } \\
\text { yields in the } 2 \text { countries }\end{array}$} & \multirow{3}{*}{$\begin{array}{l}\text { Total common } \\
\text { sires in the } \\
\text { whole pedigree }\end{array}$} & \multirow{3}{*}{$\begin{array}{l}\text { Genetic } \\
\text { similarity }\end{array}$} \\
\hline \multicolumn{2}{|c|}{ Percentage of all cows } & \multirow{2}{*}{$\begin{array}{l}\text { No. of } \\
\text { sires }\end{array}$} & & \\
\hline Luxembourg & Tunisia & & & \\
\hline 14.9 & 13.2 & 262 & 2,286 & 0.19 \\
\hline
\end{tabular}

the least connected to the Tunisian and Luxembourg females of 1999. Average relationship coefficients between the 1999 Tunisian cows and sires from the latter group of countries did not exceed $2 \%$. Those of bulls from the same group of countries as the Luxembourg subpopulation were approximately $1 \%$ (0.8 to $1.07 \%$ ).

Estimates of genetic similarities between the Luxembourg and Tunisian Holstein populations are given in Table 4. The percentage of daughters having testday records and sired by common bulls in Luxembourg and Tunisia represented 15 and $13 \%$, respectively, of the total females registered in each population. The number of common sires with daughters having milk records in each of the 2 countries was 262 .

\section{DISCUSSION}

The present study exemplifies the effects of the Holstein gene flow on the Luxembourg and Tunisian cattle populations. It illustrates the extent to which geographically distinct populations can be genetically related as a result of the extensive use of AI. Inbreeding levels in this study are comparable to those reported for most other Holstein populations (Boichard et al., 1996; Young and Seykora, 1996; Sørensen et al., 2005). The level of inbreeding observed for the Luxembourg reference population was comparable to those reported for the Irish (McParland et al., 2007) and UK (Kearney et al., 2004) Holstein populations. However, the level of inbreeding found for the Tunisian population was lower than that reported for the Canadian Holsteins $(>4 \%)$ in the same period (Van Doormaal et al., 2005). The increase in inbreeding was nearly linear, at rates of 0.23 and $0.15 \%$ per year for the Tunisian and Luxembourg populations, respectively. Kearney et al. (2004) reported a rate of $0.17 \%$ per year for the UK Holstein population for the same period. The high level of inbreeding observed in Tunisia can at least partially be explained by the use of fewer and more related sires per breeding season. Daughter group sizes per sire (Table 5) have been much larger in Tunisia than in Luxembourg in recent years. In fact, the average number of daughters per sire in Tunisia actually increased 2-fold between 1990 and 1997 compared with a nearly constant number of daughters per sire during the same period in Luxembourg. Average daughter group sizes per sire, as shown in Table 5, were relatively low in both countries, as expected by the small size of both populations. The reported average inbreeding level in Luxembourg in this study was lower than that found in Tunisia. This is probably due to its lower pedigree completeness and also to the important non-Holstein contribution of the Maas-Rhine-Yssel type Red and White animals to the original gene pool. In fact, historically around one-third of the cattle population in Luxembourg was Maas-Rhine-Yssel type Red and White animals. This source of genetic diversity has been eroded by the massive use of purebred Red Holstein sires since the 1980s.

Measures based on probabilities of gene origin used to evaluate genetic diversity in the Luxembourg and Tunisian reference populations show that both populations are derived from small numbers of founding animals. The effective numbers of founders and ancestors for the Luxembourg population were slightly higher than those obtained for the Tunisian population, indicating that the number of animals contributing to the gene pool was low in the case of the Tunisian population. The total numbers of founders (in Tunisia and in Luxembourg) were high in this study because of missing pedigree information (an animal was regarded as a founder if its parents were declared unknown). A low ratio of the effective number of founders to the total number of founders (f) implies an unbalanced use of founders, missing pedigree information, or both. Indeed, a substantial disequilibrium was found for the 2 populations. The ratio $\mathrm{f}_{\mathrm{e}} / \mathrm{f}$ was 0.02 and 0.04 in 2000 for Tunisia and Luxembourg, respectively. Nevertheless, the ratios found in this study are higher than the 0.002 found in Irish Friesian Holsteins (McParland et al., 2007) and also to the 0.0002 reported for French Holsteins (Boichard et al., 1996). These results show that the ratio $\mathrm{f}_{\mathrm{e}} / \mathrm{f}$ can only be compared for populations that have a similar size. However, the ratio $\mathrm{f}_{\mathrm{e}} / \mathrm{f}$ in 2000 for Tunisia was still similar to those found in Austrian Brown Swiss populations (0.016; Sölkner et al., 1998) and the French Tarentais populations (0.017; Boichard et al., 1996).

The effective number of ancestors (founders or not) is the parameter most affected by the quality of pedigrees (Boichard et al., 1997). Estimates of the effective number of ancestors of female populations born in 2000 were 44 and 22 from the Luxembourg and Tunisian data, respectively. In Tunisian Holsteins, this parameter was similar to the value (20.6) reported by Sørensen et al. (2005) for the Danish Holsteins, but was still lower than the value (93) found for the British Holstein-Friesian population (Roughsedge et al., 
Table 5. Daughter group sizes and average relationships among their sires for the reference populations of cows born between 1990 and 2000 in Tunisia and Luxembourg

\begin{tabular}{|c|c|c|c|c|c|c|}
\hline \multirow{2}{*}{$\begin{array}{l}\text { Year of } \\
\text { birth }\end{array}$} & \multicolumn{2}{|c|}{$\begin{array}{l}\text { Average number of } \\
\text { daughters/sire }\end{array}$} & \multicolumn{2}{|c|}{$\begin{array}{l}\text { Maximum number of } \\
\text { daughters/sire }\end{array}$} & \multicolumn{2}{|c|}{$\begin{array}{l}\text { Average genetic relationships } \\
\text { among their sires, } \%\end{array}$} \\
\hline & Tunisia & Luxembourg & Tunisia & Luxembourg & Tunisia & Luxembourg \\
\hline 1990 & 7 & 9 & 487 & 188 & 2.01 & 0.95 \\
\hline 1991 & 7 & 9 & 210 & 215 & 2.04 & 1.08 \\
\hline 1992 & 7 & 8 & 272 & 290 & 2.10 & 1.18 \\
\hline 1993 & 7 & 8 & 314 & 225 & 2.17 & 1.35 \\
\hline 1994 & 8 & 9 & 331 & 355 & 2.74 & 1.43 \\
\hline 1995 & 7 & 9 & 338 & 295 & 2.76 & 1.53 \\
\hline 1996 & 7 & 9 & 200 & 203 & 2.93 & 1.65 \\
\hline 1997 & 10 & 7 & 300 & 122 & 3.41 & 1.64 \\
\hline 1998 & 8 & 9 & 278 & 209 & 3.47 & 1.79 \\
\hline 1999 & 15 & 9 & 393 & 216 & 4.05 & 1.83 \\
\hline 2000 & 14 & 9 & 274 & 172 & 4.41 & 1.98 \\
\hline
\end{tabular}

1999). The British results may be explained by a still relatively important influence of British Friesians in 1999. The effective number of ancestors for the Luxembourg population was similar to the value (43) reported by Boichard et al. (1996) for the French Holsteins.

The comparison between the effective number of founders and the effective number of ancestors reveals the reduction of genetic variability in populations that have passed through bottlenecks (Boichard et al. 1997). Effective numbers of ancestors were lower than effective numbers of founders in both populations of the study. The ratio $f_{a} / f_{e}$ was 0.15 and 0.19 in 2000 for the Luxembourg and Tunisian populations, respectively. These ratios were lower than the 0.30 for the French Holstein (Boichard et al., 1996) and 0.29 for the Danish Holstein (Sørensen et al., 2005) populations. Despite a larger total number of founders in the Tunisian population, its effective numbers of founders and of ancestors were smaller than those of the Luxembourg population (Table 1). The observed numbers show that the expected contributions of founders, ancestors, or both were more unbalanced in the Tunisian than in the Luxembourg population. This can be partially explained by differences in pedigree depths between the 2 populations and by the contribution of the Maas-Rhine-Yssel type Red and White animals to the Luxembourg gene pool.

Average additive relationship coefficients between the 2 female reference populations were smaller than the Tunisian relationship coefficients but were comparable to those of the Luxembourg population. Percentages of females with known parents represented 86 and $64 \%$ of the Tunisian and Luxembourg reference populations, respectively. The average genetic relationship among Tunisian females born between 1993 and 1996 was comparable to the $2.2 \%$ found in the same period between French Holstein cows (Moureaux et al., 2003). Links among the Luxembourg and Tuni- sian populations essentially seem to be due to the use of semen from bulls with common ancestors. These 2 populations share the same major ancestors. Eight of the 10 most important ancestors were common for the 2 reference populations. Seven of them were also found among the 10 most important contributors to Danish Holsteins (Sørensen et al., 2005), with genetic contributions comparable to those found for the Tunisian reference population. The 2 top-ranked contributors to Danish Holsteins were Round Oak Rag Apple Elevation with $13.8 \%$ and Pawnee Farm Arlinda Chief with 10.9\%. Thus far, these same sires have contributed, respectively, 10.35 and $10.7 \%$ to the Tunisian population. Together, Elevation and Chief have contributed 13.6 and $21 \%$ to the Luxembourg and Tunisian reference populations, respectively. They are also the same most contributing ancestors to the American Holstein populations (Young and Seykora, 1996). Genetic links between the Luxembourg and Tunisian populations can also be explained by Tunisian pregnant heifer imports from Germany between 1993 and 2000. In fact, Luxembourg ancestors have close links with the German population. Almost half the Luxembourg ancestors originated from Germany and the Netherlands ( 34.5 and $13 \%$, respectively), although only 6 and $2.5 \%$ of Tunisian ancestors are from Germany and the Netherlands, respectively. The Tunisian and Luxembourg Holstein reference populations share almost the same proportion of ancestors originating from Canada (12.5 and $13.5 \%$ of the total ancestors, respectively). On the other hand, the Tunisian Holstein population has a higher number of genes originating from the US Holstein ( $71.5 \%$ of ancestors) than the Luxembourg population (38.5\% of ancestors).

Additive relationships obtained among sires used by the 2 reference populations were higher than those obtained among females in both countries. Similar results were found inside the French Holstein population 
(Moureaux et al., 2003), where average additive relationships among AI sires born between 1991 and 1995 were 2 times higher than those obtained among females born between 1993 and 1996. Genetic relationships among sires used in Luxembourg and in Tunisia result from the use of a limited number of Holstein sires. Van Doormaal et al. (2005) reported that Elevation (the most contributing ancestor to the Luxembourg and Tunisian Holstein reference population) had at least $94 \%$ of the 1999-born proven sires as descendants in 11 of the 13 important Interbull countries. The 1999 female subpopulations defined for both countries were related to exactly the same group of bulls in Interbull countries. Only a difference in the level of the relationship was observed, which might be explained by the presence of Red ancestors in the Luxembourg Holstein population. Except for a difference in the level of genetic relationship values, Van Doormaal et al. (2005) also found that the Canadian Holstein population born in 2004 was related in a very similar fashion to 1999-proven bulls in Interbull countries. From their analysis, the proven bulls from Canada, Spain, Japan, Italy, and United States had the highest percentage of genes in common with the Canadian Holstein population born in 2004, with a genetic relationship value of more than $9 \%$. Proven bulls born in Australia, Ireland, New Zealand, and Poland were those with the smallest additive relationship to Canadian Holstein heifers born in 2004. A similar result was found for Luxembourg and Tunisian populations in this study.

Measures of genetic similarity asserted the presence of genetic links between the Luxembourg and Tunisian populations. These links are, for example, greater than those reported between the Nordic Holstein and Ayrshire populations (Pedersen et al., 2001). Proportions of daughters with common sires were 14.9 and $13.2 \%$ of all cows in Luxembourg and in Tunisia, respectively (Table 4). Corresponding proportions were only 2.8 and $2.3 \%$ in Swedish and Finnish Holstein populations, and 10.0 and $1.3 \%$ in Danish and Finnish Holstein populations, respectively. The Swedish and Danish Holsteins are more connected, and the respective proportions of daughters with common sires in these 2 populations were 10.2 and $20.7 \%$.

The results of this study allowed the genetic structure of the Holstein breed in Tunisia and Luxembourg to be characterized. Breeding schemes are based on semen and some heifer imports in both countries. In Tunisia, breeding decisions are based on recorded yield or an intraherd index for cows, and essentially on a milk yield index for AI bulls. However, breeding decisions do not take into account traits other than milk yield, such as fertility, longevity, and morphology. The inclusion of these traits in breeding goals could allow the use of other bulls, and consequently the enrichment of the gene pool, as has been the case in Luxembourg in recent years. The average relatedness parameter (VanRaden and Smith, 1999) could be a means to monitor genetic variability and to plan mating. However, there should be greater efforts to enhance pedigree recording of Tunisian and Luxembourg cattle populations for an appropriate monitoring of genetic variability.

\section{CONCLUSIONS}

Pedigrees of the Luxembourg and Tunisian Holstein populations were analyzed simultaneously. Pedigree completeness level was partial in both populations. Rates of change in inbreeding were 0.23 and $0.15 \%$ per year between 1990 and 2000 for the Tunisian and Luxembourg populations, respectively. Respective inbreeding levels were up to 3.10 and $2.12 \%$ in 2000 . Inbreeding estimates from the Luxembourg data were lower than those from the Tunisian data, probably because of a relatively greater diversity of gene origin in the Luxembourg population and lower pedigree completeness. Furthermore, breeders from Luxembourg have used a few young bulls in recent years.

Average additive relationship coefficients and genetic similarity have also increased, indicating that indirect genetic links have been developing between the 2 populations. Average additive relationships between the 2 populations were greater than $2 \%$ in 2000 . The 2 populations considered in this study have close genetic links that may allow studies of genotype by environment interactions.

The use of new bulls is recommended in both populations for enrichment of the gene pool. Breeding plans should focus on genetic gain maximization and also on the maintenance of genetic diversity. Mating plans involve having knowledge of the genealogical affiliation of candidate animals. Therefore, there should be greater efforts to enhance pedigree recording of the Tunisian and Luxembourg cattle populations.

\section{ACKNOWLEDGMENTS}

Hedi Hammami acknowledges the support of the Luxembourg Ministry of Culture, Higher Education and Research through a grant scholarship (BFR0461). Coraline Croquet, research fellow, and Nicolas Gengler, research associate, acknowledge the support of the National Fund for Scientific Research (Brussels, Belgium) through grants F.4552.05 and 2.4507.02 F (2). The first author also thanks the Luxembourg HerdBook Federation (now CONVIS Herdbuch, Service 
Elevage et Génétique) and the Tunisian Livestock and Pasture Office (OEP) for providing data.

\section{REFERENCES}

Boichard, D. 2002. Pedig: A Fortran package for pedigree analysis suited for large populations. In Proc. 7th World Congr. Genetics Applied to Livest. Prod., Montpellier, France. CD-Rom. Comm. no. 28-13.

Boichard, D., L. Maignel, and E. Verrier. 1996. Analyse généalogique des races bovines françaises. INRA Prod. Anim. 9:323-335.

Boichard, D., L. Maignel, and E. Verrier. 1997. Value of probabilities of gene origin to measure the genetic variability in a population. Genet. Sel. Evol. 29:5-23.

Croquet, C., P. Mayeres, A. Gillon, S. Vanderick, and N. Gengler. 2006. Inbreeding depression for global and partial economic indexes, production, type and functional traits. J. Dairy Sci. 89:2257-2267.

Djemali, M., and P. J. Berger. 1992. Yield and reproduction characteristics of Friesian cattle under North African conditions. J. Dairy Sci. 75:3568-3575.

Gutiérrez, J. P., J. Marmi, F. Goyache, and J. Jordana. 2005. Pedigree information reveals moderate to high levels of inbreeding and a weak population structure in the endangered Catalonian donkey breed. Anim. Breed. Genet. 122:378-386.

Hagger, C. 2005. Estimates of genetic diversity in the brown cattle population of Switzerland obtained from pedigree information. Anim. Breed. Genet. 122:405-413.

Honda, T., T. Nomura, Y. Yamaguchi, and F. Mukai. 2004. Monitoring of genetic diversity in the Japanese Black cattle population by the use of pedigree information. Anim. Breed. Genet. 121:242-252.

Kearney, J. F., E. Wall, B. Villanueva, and M. P. Coffey. 2004. Inbreeding trends and application of optimized selection in the UK Holstein population. J. Dairy Sci. 87:3503-3509.

Lacy, R. C. 1989. Analysis of founder representations in pedigrees: Founder equivalents and founder genome equivalents. Zoo Biol. $8: 111-123$

Leroy, G., X. Rognon, A. Varlet, C. Joffrin, and E. Verrier. 2006. Genetic variability in French dog breeds assessed by pedigree data. Anim. Breed. Genet. 123:1-9.
McParland, S., J. F. Kearney, M. Rath, and D. P. Berry. 2007. Inbreeding trends and pedigree analysis of Irish dairy and beef cattle populations. J. Anim. Sci. 85:322-331.

Meuwissen, T. H. E., and Z. Luo. 1992. Computing inbreeding coefficients in large populations. Genet. Sel. Evol. 24:305-313.

Miglior, F., B. L. Muir, and B. J. Van Doormaal. 2005. Selection indices in Holstein cattle of various countries. J. Dairy Sci. 88:1255-1263.

Moureaux, S., D. Boichard, and E. Verrier. 2003. Utilisation de l'information généalogique pour l'estimation de la variabilité génétique de huit races bovines laitières françaises d'extension nationale ou régionale. http://www.inst-elevage.asso.fr/html1/ IMG/pdf/VARBL3R00.pdf Accessed May 14, 2007.

Pedersen, J., C. Langdahl, J. Pösö, and K. Johansson. 2001. A joint Nordic animal model for milk production traits in Holsteins and Ayrshires. Interbull Bull. 27:3-8.

Rekaya, R., K. A. Weigel, and D. Gianola. 2003. Bayesian estimation of parameters of a structural model for genetic covariances between milk yields in five regions of the United States. J. Dairy Sci. 86:1837-1844.

Roughsedge, T., S. Brotherstone, and P. M. Visscher. 1999. Quantifying genetic contributions to a dairy cattle population using pedigree analysis. Livest. Prod. Sci. 60:359-369.

Sölkner, J., L. Filipcic, and N. Hampshire. 1998. Genetic variability of populations and similarity of subpopulations in Austrian cattle breeds determined by analysis of pedigrees. J. Anim. Sci. 67:249-256.

Sørensen, A. C., M. K. Sørensen, and P. Berg. 2005. Inbreeding in Danish dairy cattle breeds. J. Dairy Sci. 88:1865-1872.

Valera, M., A. Moulina, J. P. Gutiérrez, J. Gómez, and F. Goyache. 2005. Pedigree analysis in the Andalusian horse: Population structure, genetic variability and influence of the Carthusian strain. Livest. Prod. Sci. 95:57-66.

Van Doormaal, B. J., F. Miglior, G. Kistemaker, and P. Brand. 2005. Genetic diversification of the Holstein breed in Canada and internationally. Interbull Bull. 33:93-97.

VanRaden, P. M., and L. A. Smith. 1999. Selection and mating considering expected inbreeding of future progeny. J. Dairy Sci. 82:2771-2778.

Young, C. W., and A. J. Seykora. 1996. Estimates of inbreeding and relationship among registered Holstein females in the United States. J. Dairy Sci. 79:502-505. 